\title{
Erratum
}

Gefässchirurgie 2018 $\cdot 23: 392$

https://doi.org/10.1007/s00772-018-0436-2

Published online: 16 August 2018

(c) Springer Medizin Verlag GmbH, ein Teil von Springer Nature 2018

CrossMark

C.-A. Behrendt • H. C. Rieß - T. Schwaneberg · F. Heidemann - N. Tsilimparis · A.-A. Larena-Avellaneda $\cdot$ H. Diener $\cdot$ T. Kölbel · E. S. Debus

Department of Vascular Medicine, University Heart Center Hamburg, University Medical Center HamburgEppendorf, Hamburg, Germany

\section{Erratum to: Complex endovascular treatment of intact aortic aneurysms. An analysis of health insurance claims data}

\section{Erratum to:}

Gefässchirurgie (2018)

https://doi.org/10.1007/s00772-018-

0387-7

The article was wrongly published under the article type "Review". Please note that the article is an "Original Paper".

The publisher apologizes to the authors and readers.

\section{Corresponding address}

\section{Dr. C.-A. Behrendt}

Department of Vascular Medicine, University Heart Center Hamburg, University Medical

Center Hamburg-Eppendorf

Hamburg, Germany

ch.behrendt@uke.de 